\title{
Human Toxoplasma gondii infection in Nigeria: a systematic review and meta- analysis of data published between 1960 and 2019
}

Solomon Ngutor Karshima ${ }^{1 *}$ (D) and Magdalene Nguvan Karshima²

\begin{abstract}
Background: Over 70\% of the worlds' population is infected by Toxoplasma gondii; a pathogen capable of causing cerebral toxoplasmosis in HIV patients and neonatal complications like miscarriage, chorioretinitis, hydrocephalus, cerebral calcification and foetal death in the third trimester of pregnancy. In spite of this, the burden of this zoonotic pathogen is poorly understood in Nigeria. The aim of the present study therefore, is to determine the burden of T. gondii among normal individuals, HIV patients and pregnant women as well as the distribution of the infection across Nigeria.

Methods: Using the PRISMA guidelines, we conducted a systematic review and meta-analysis of data retrieved from six electronic databases (AJOL, Google Scholar, PubMed, Scopus, Science Direct and Web of Science). Pooled prevalence (PP) and heterogeneity were determined by the random-effects model and the Cochran's Q-test respectively. The quality of each study and publication bias were assessed by the 9 point Joanna Briggs Institute Critical Appraisal Instrument and the Egger's regression asymmetry test respectively, while the robustness of a pooled estimate was tested by the single study omission analysis.

Results: Exactly 5834 of the 16,230 individuals examined for T. gondii infection by 50 studies across 17 Nigerian States were positive for the infection. Overall PP was 32.92\% (95\% Cl: 27.89, 38.37), with a range of $14.41 \%$ (95\% Cl: $5.32,33.54)$ to $86.82 \%(95 \% \mathrm{Cl}: 66.13,95.69)$ across sub-groups. Pooled prevalence was significantly higher ( $p<$ $0.001)$ among pregnant women $(40.25 \%$; $95 \% \mathrm{Cl}: 33.19,47.73)$ and HIV patients $(31.68,95 \% \mathrm{Cl}: 20.53,45.41)$ than normal individuals $(23.32,95 \% \mathrm{Cl}: 17.25,30.75)$. T. gondii prevalence declined by over $58 \%$ during the 59 years reviewed.

Conclusion: Toxoplasma gondii infection is moderately prevalent in Nigeria. Highest prevalence estimates were observed among pregnant women and in the south-south region. For effective control of the disease in Nigeria, a holistic approach involving on-farm, environmental, public health and animal components are suggested.
\end{abstract}

Keywords: Geographical distribution, HIV patients, Normal individuals, Pregnant women, Prevalence, Toxoplasma gondii

\footnotetext{
* Correspondence: torkarshima@yahoo.co.uk

1 Department of Veterinary Public Health and Preventive Medicine, University of Jos, PMB 2084, Jos, Nigeria

Full list of author information is available at the end of the article
}

(c) The Author(s). 2020 Open Access This article is licensed under a Creative Commons Attribution 4.0 International License, which permits use, sharing, adaptation, distribution and reproduction in any medium or format, as long as you give appropriate credit to the original author(s) and the source, provide a link to the Creative Commons licence, and indicate if changes were made. The images or other third party material in this article are included in the article's Creative Commons licence, unless indicated otherwise in a credit line to the material. If material is not included in the article's Creative Commons licence and your intended use is not permitted by statutory regulation or exceeds the permitted use, you will need to obtain permission directly from the copyright holder. To view a copy of this licence, visit http://creativecommons.org/licenses/by/4.0/. The Creative Commons Public Domain Dedication waiver (http://creativecommons.org/publicdomain/zero/1.0/) applies to the data made available in this article, unless otherwise stated in a credit line to the data. 


\section{Background}

Toxoplasma gondii is an obligate intracellular protozoan zoonotic pathogen of almost all warm-blooded animals including humans and birds [1]. The infection is worldwide in distribution and over $70 \%$ of the worlds' population is infected [2,3]. Domestic cats are the definitive hosts, and represent the main source of infection through oocysts passed in their faeces. The pathogen is currently a global problem which is present in every country of the world [4].

Human infection may result via several routes including contact with infected cats, the consumption of animal tissues infected by cysts of $T$. gondii, the ingestion of food or water contaminated with oocysts excreted in the faeces of cats, blood transfusion and intrauterine [5-7]. Transmission is influenced by factors such as environmental conditions, host immune status, cultural behaviour, individual's hygienic practices, type of food and cooking methods $[8,9]$.

In immunocompetent individuals, Toxoplasma infection may be asymptomatic or self-limiting. However, immunocompromised conditions like HIV infection may alter the clinical course of $T$. gondii infection $[10,11]$. HIV infection may cause reactivation of the asymptomatic Toxoplasma infection resulting in neurological signs like headache, disorientation, drowsiness, hemiparesis, reflex changes and convulsion [12-14]. About 25-50\% of HIV immunocompromised individuals may show the signs of cerebral toxoplasmosis [15] and Toxoplasma infection is now a known cause of morbidity and mortality in people living with HIV and AIDS (PLWHA) [12].

Toxoplasma induced neonatal complications especially during third trimester of pregnancy may include miscarriage, chorioretinitis, hydrocephalus, cerebral calcification and foetal death $[16,17]$. The risk of transmission of Toxoplasma infection from mother to child intrauterine is increased during the third trimester of pregnancy $[18,19]$. Continental prevalence of $T$. gondii across the world ranged between $4.3-75.0 \%$ in Africa [20-23], 14.0-96.3\% in Asia [24-26], 6.8-51.8\% in Europe [27-29], $10.6-13.0 \%$ in North America [30-32] and 26.3-80.0\% in South America [33-35].

Despite the association of toxoplasmosis with immunocompromised conditions and the increasing number of PLWHA and pregnant women in Nigeria, the nationwide prevalence and burden of $T$. gondii infection are poorly understood. In this study, we reported the burden of $T$. gondii infections among normal individuals, HIV patients and pregnant women in Nigeria. It is envisaged that the present finding will enable stakeholders and policy makers in the health sector to re-strategize on the control of toxoplasmosis, thus reducing the burden of the disease especially in Nigerian pregnant women.

\section{Methods}

\section{Study protocol and literature search procedure}

We conducted a systematic review and meta-analysis using the guidelines provided by Moher [36] for Preferred Reporting Items for Systematic Reviews and Meta-Analyses (PRISMA). Inclusion of data for quantitative synthesis was based on the PRISMA checklist (Additional file 1), and the infection of humans with Toxoplasma gondii was the outcome of interest. The review protocol was registered on PROSPERO International prospective register of systematic reviews with registration number CRD42019135416 and available from: http://www. crd.york.ac.uk/PROSPERO/display_record.php?ID=CRD42 019135416.

Six electronic databases: African Journals OnLine (AJOL), Google Scholar, PubMed, Scopus, Science Direct and Web of Science were systematically searched between 1st June and 30th April 2020 for literature published on $T$. gondii infection in humans in Nigeria between 1960 and 2019. Additional studies were obtained through searching of list of references of retrieved studies and by contacting editors of Nigerian biomedical journals. Full articles with only visible online abstracts were requested from authors and editors of the publishing journals through phone calls or e-mails. The $\mathrm{MeSH}$ search string employed in PubMed was "toxoplasmosis" OR "Toxoplasma" OR "Toxoplasma gondii" OR "Toxoplasma infections" AND "Prevalence" OR "Seroprevalence" OR "Seroepidemiology" AND "Humans" OR "Healthy individuals" OR "HIV patients" OR "Pregnant women" AND "North-central" OR "North-eastern" OR "North-western" Or "South-eastern" OR "South-south" OR "South-western" AND "Nigeria". Search on AJOL was carried out on journal by journal bases within biomedical journals indexed in the database. Due to the large volume of data in Google Scholar, the study customised article search in this database based on year of publication for ease of sorting articles.

\section{Requirements for inclusion}

Studies were subjected to two stages of screening for either inclusion or exclusion. In the first stage, studies were screened by scanning through titles for exclusion of duplicates. Second stage screening involved detailed review of abstract and full text for removal of irrelevant studies and identification of relevant information. A study was considered for inclusion if it had the following characteristics: (i) it was carried out in Nigeria, (ii) it was published in English, (iii) it was carried out and published between January 1960 and December 2019, (iv) it was a cross sectional or prevalence study, (v) it stated the study location, (vi) it clearly stated the number of sample size and positive cases, (vii) it reported T. gondii in humans, and (viii) it stated the target population. 
Studies that did not meet these inclusion criteria and all unpublished articles were excluded.

\section{Quality assessment}

The quality of each article analysed was assessed independently using the 9 point Joanna Briggs Institute (JBI) critical appraisal instrument for studies reporting prevalence data [37]. The JBI checklist posed nine questions viz.: (1) Was the sample frame appropriate to address the target population? (2) Were study participants recruited in an appropriate way? (3) Was the sample size adequate? (4) Were the study subjects and setting described in detail? (5) Was data analysis conducted with sufficient coverage of the identified sample? (6) Were valid methods used for the identification of the condition? (7) Was the condition measured in a standard, reliable way for all participants? (8) Was there appropriate statistical analysis? (9) Was the response rate adequate, and if not, was the low response rate managed appropriately (Additional file 2)? Answers to the aforementioned questions for individual studies were respectively assigned scores of 0 or 1 for no or yes answers, while $U$ or NA were used when a study does not clearly answer the question or when the question was not applicable to the study. For a study to be included in the quantitative synthesis, it was required to have a minimum quality assessment score of 6 (66.7\%); that is answering yes to at least 6 of the 9 questions on the checklist.

\section{Extraction of data}

To ensure data validation and increase the likelihood of detecting errors, literature search, screening of articles, selection of articles for eligibility and data extraction were performed by both authors (SNK and MNK) independently. However, in cases of discrepancies, both authors crosschecked data simultaneously and discussed issues until consensus was reached. Data pulled out from each published study were name of author, the year the study was carried out, the year it was published, sample size, number of positive cases, study location, study design, method of diagnosis, diagnostic target and characteristics of study population. Where specified, the gender and ages of study population were also extracted and individuals within the age brackets $\leq 17$ years of age were categorised as children while those $\geq 18$ years of age were categorised as adults. Where the study year for any article was not stated, the year preceding its publication year was considered as the year it was conducted.

In our PICOS, we answered questions such as: (1) What is the burden of Toxoplasma gondii infection in normal individuals, HIV patients and pregnant women from Nigeria? (2) Is the burden greater among immunocompromised than normal individuals? (3) What is the distribution pattern of the infection across Nigeria? For the purpose of the present study, an individual was said to be infected with $T$. gondii only if the individual tested positive for the parasite by microscopic, serological or molecular techniques, normal individuals refers to individuals without any history of pregnancy or any immunocompromised conditions like HIV/AIDS and neoplasia, pregnancy refers to a state where a woman carried an embryo or foetus for a period of \pm 9 months and HIV patients refer to people living with HIV/AIDS. More so, for the purpose of our analysis, diagnostic methods like polymerase chain reaction (PCR) and immunochromatography which were utilized by only one study, latex agglutination test (LAT) which was utilized by only two studies and studies with unidentified methods of diagnosis were grouped as others.

\section{Data collation and analyses}

Preliminary analyses including summations, subtractions, divisions, multiplications and estimation of percentages were conducted using Microsoft Excel. Statistical and meta-analyses were carried out using Graph-Pad Prism version 4.0 and Comprehensive MetaAnalysis version 3.0 respectively. Prevalence of individual studies was determined by expressing the proportion of positive cases of $T$. gondii infection and sample size as percentages.

\section{Pooling, sub-group and heterogeneity analyses}

Pooled prevalence and their 95\% Confidence Interval (CI) were estimated by the random-effects model [38]. Sub-group analyses were performed based on ages (Adult, children), gender (female, male), characteristics of study population (normal individuals, HIV patients and pregnant women) and geographic regions (Northcentral, north-east, north-west, south-east, south-south and south-west). Others were diagnostic methods (Dye test, ELISA, HAT, LAT, PCR, and RSAT), study period (1960-1975, 1976-1990, 1991-2005 and 2006-2019) as well as sample size ( $\leq 150,151-300,301-450$ and $>450)$.

Heterogeneity among studies was evaluated using the Cochran's Q-test while the percentage variation among studies due to heterogeneity was quantified using the formula $I^{2}=100 \times(\mathrm{Q}-d f) / \mathrm{Q}$; where $\mathrm{Q}$ is Cochran's heterogeneity statistic and $d f$ is the degree of freedom which is determined by subtracting one from the number of studies analysed. I-square values of $0,25,50$ and $75 \%$ were considered no, low, moderate and substantive heterogeneities respectively $[39,40]$.

Publication bias, sensitivity and meta-regression analyses Publication bias (across-study bias) was examined by funnel plots while the statistical significance was assessed by the Egger's regression asymmetry test [41]. The unbiased estimates were calculated using the Duval 
and Tweedie non-parametric 'fill and trim' linear random method [42]. The robustness of a pooled estimate was tested by the single study omission analysis, and a study was considered to have no influence on the pooled prevalence if the pooled estimate without it (i.e number of studies $=49$ ) was within the $95 \%$ confidence limits of the overall pooled prevalence when number of studies equals 50 [43]. Meta-regression analysis was performed for different sub-groups including year of conduct of study, diagnostic methods, geographic regions as well as age, gender and characteristics of the study population to determine the possible sources of heterogeneity.

\section{Results}

\section{Literature search and eligible studies}

The procedure for selection of eligible studies is presented in Fig. 1. A total of 79 studies resulted from the search of six electronic databases. Twenty five of the studies were duplicates and were removed after screening of titles. Fifty four of the studies were subjected to detailed review of abstract and full text. Four studies were thereafter removed for insufficiency of data on sample sizes and number of cases $(n=3)$ and lack of information on study location $(n=1)$. Fifty studies were subjected to the quantitative synthesis. None of the studies assessed for quality by the JBI critical appraisal instrument was excluded for lack of merit. Quality scores ranged between 6 and 8 (66.67-88.89\%) of a total of 9 scores (Table 1 and Additional file 3).

\section{Characteristics of eligible studies}

Table 1 shows the characteristics of the eligible studies. Fifty studies examined 16,230 individuals for Toxoplasma gondii infection among Nigerians and reported prevalence rates ranging between 2.00 and $88.24 \%$. Nine,
$4,10,8$ and 19 of the studies were reported in the north-central, north-eastern, north-western, south-south and the south-western regions respectively. Three studies utilized rapid slide agglutination test (RSAT) for diagnosis, 4 each were diagnosed using dye and haemagglutination tests, 28 of the studies utilized enzyme linked immunosorbent assay (ELISA) while 11 studies utilized other methods (immunochromatographic test 1 , LAT 2, PCR 1 and unidentified tests 7). One study each targeted Toxoplasma-immunoglobulin M (IgM) and deoxyribonucleic acid (DNA), 20 studies targeted Toxoplasma-immunoglobulin G (IgG), 17 targeted both IgG and IgM, while 11 studies failed to state their diagnostic targets. Two studies were reported between 1960 and 1975, 6 between 1976 and 1990, 5 between 1991 and 2005 and 37 between 2006 and 2019. Twelve, 18, 13 and 7 of the studies had sample sizes of $\leq 150,151-300$, $301-450$ and $>450$ respectively.

\section{Spatial distribution of eligible studies}

The 50 studies were reported across 5 of the 6 regions of Nigeria as presented in Fig. 2. The nine (18.00\%) studies reported across the north-central region were distributed as follow: one each in Kwara and Niger States, 2 each in Abuja and Benue State, and 3 in Plateau State. Four $(8.00 \%)$ studies were reported in Borno State, North-east Nigeria while the $10(20.00 \%)$ studies reported across the north-west region were from Kaduna and Sokoto (3 studies each) and 4 from Kano. One study each was reported from Akwa Ibom and Delta States and 3 each from Edo and Rivers States totally 8 (16.00\%) studies from the south-south while the $19(38.00 \%)$ studies distributed across the south-west; 1, 2, 6 and 10 were from Ogun, Osun, Oyo and Lagos States respectively. No study was reported in the south-east region.

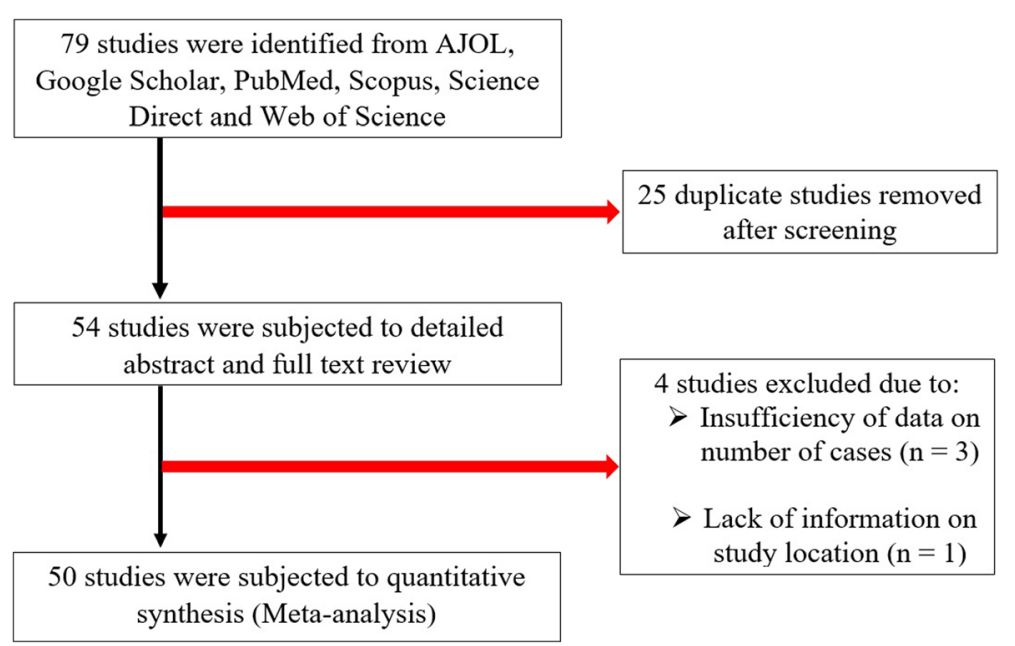

Fig. 1 Flow diagram for the selection of eligible studies 


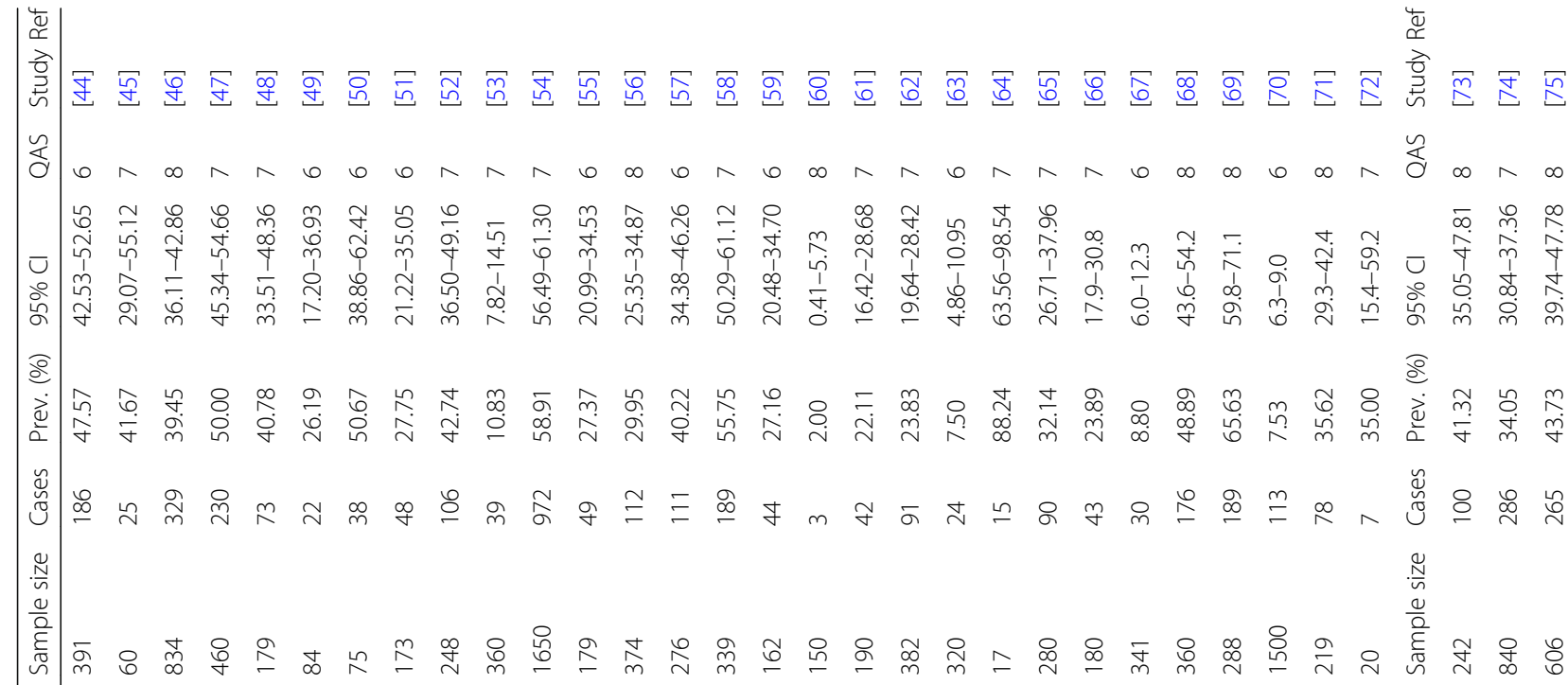

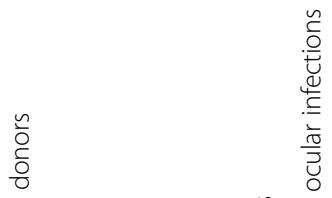

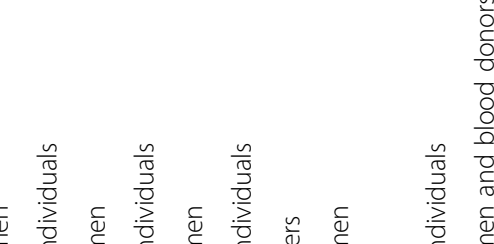

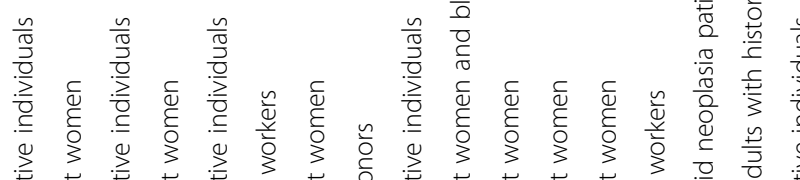

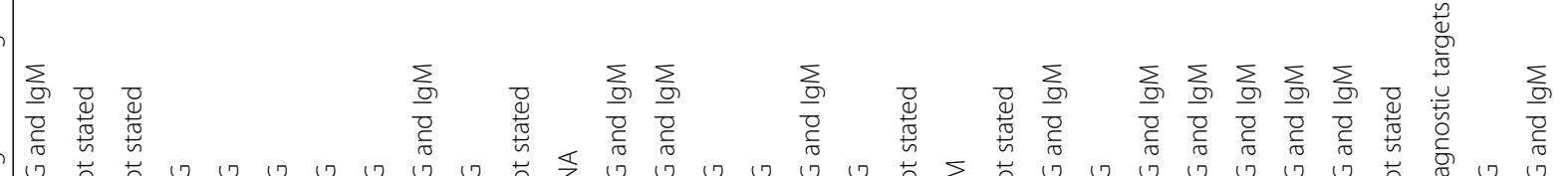

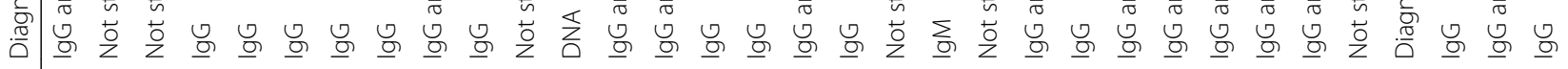




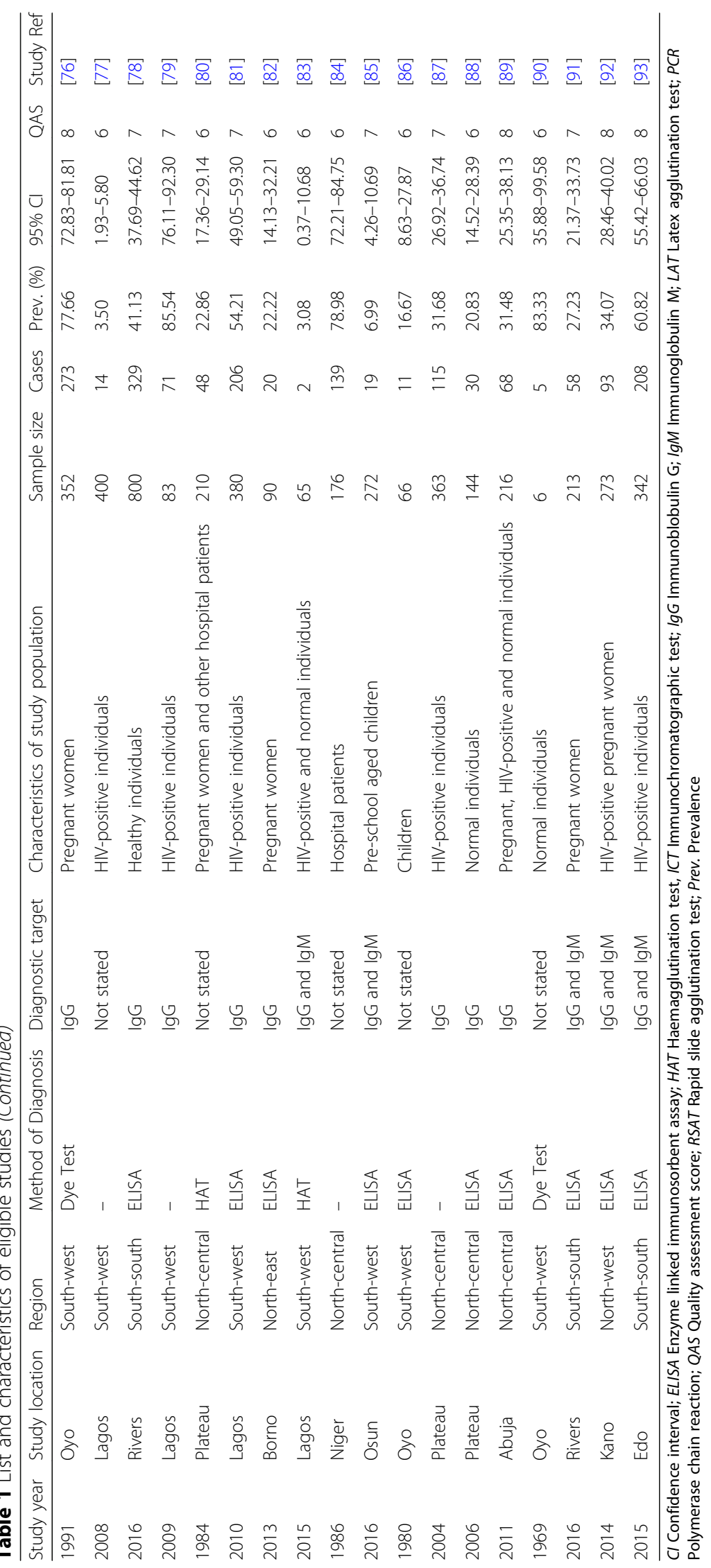




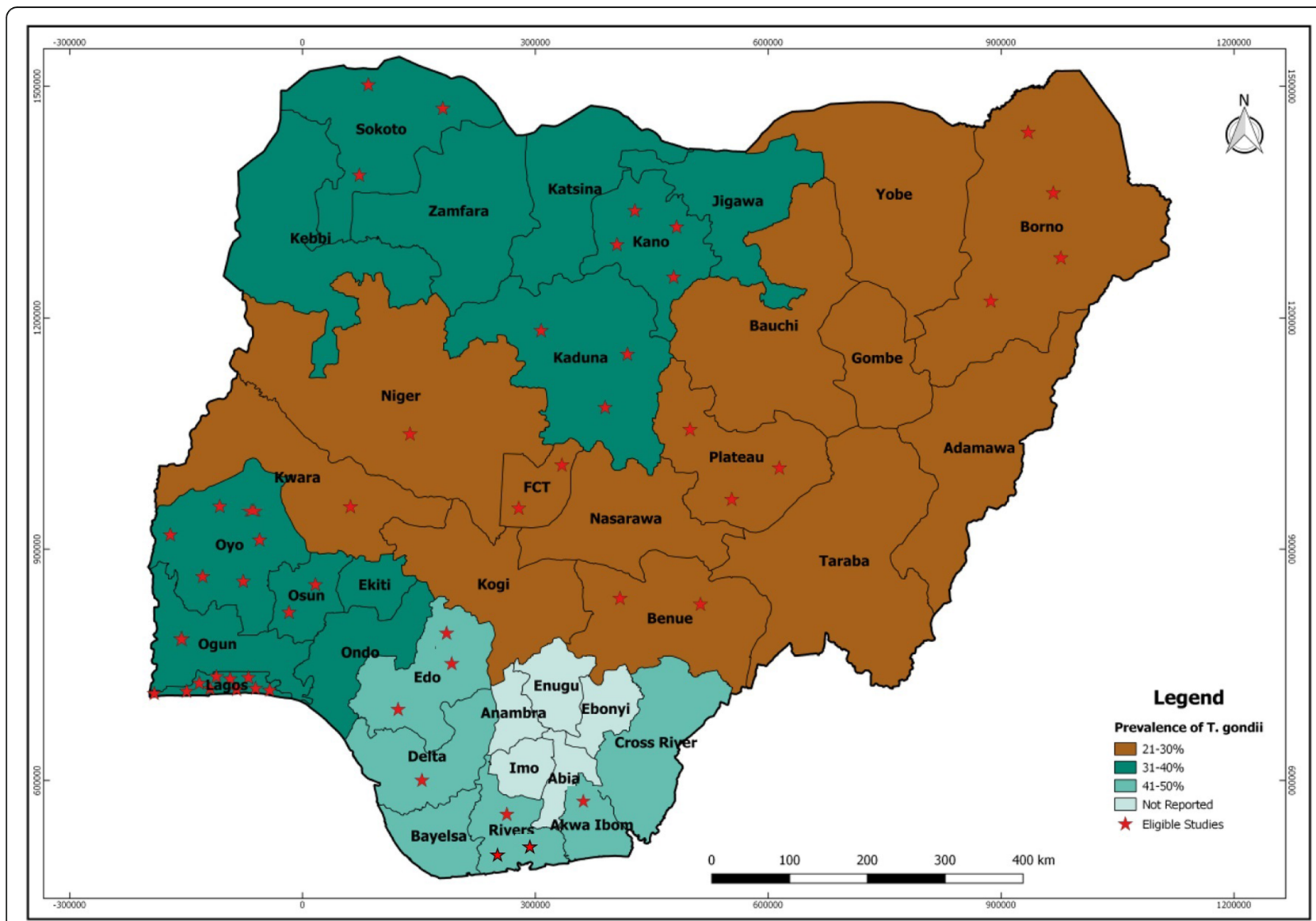

Fig. 2 Regional prevalence of T. gondii and distribution of eligible studies in Nigeria

\section{Pooled prevalence and heterogeneity analysis}

Pooled prevalence and heterogeneities are presented in Tables 2 and 3 as well as Figs. 3 and 4. Fifty studies reported 5834 positive cases of Toxoplasma gondii infection among 16,230 individuals examined from 17 Nigerian States. Overall PP was 32.92\% (95\% CI: 27.89, 38.37; Q- $p<0.001$ ) with ranges of 28.58 (95\% CI: 16.28 , 45.17; Q- $p<0.001$ ) to $41.00 \%$ (95\% CI: 25.61, 58.37; Q$p<0.001)$ across geographic regions, $14.41 \%(95 \% \mathrm{CI}$ : 5.32, 33.54; Q-p < 0.001) to $74.29 \%$ (95\% CI: 57.49, 86.06; Q- $p<0.001)$ across methods of diagnosis, 28.75 (95\% CI: 23.44, 34.71; Q- $p<0.001$ ) to $86.82 \%$ (95\% CI: 66.13, 95.69; Q-p: 0.760) across study periods and $30.22(95 \%$ CI: $19.87-43.07$; Q- $p<0.001$ ) to $36.64 \%$ (95\% CI: 24.15 , 51.23; Q-p < 0.001) across sample size.

Pooled prevalence of $T$. gondii infection among adults and children were $36.93 \%$ (95\% CI: 29.04, 45.59; Q-p < $0.001)$ and $18.52 \%$ (95\% CI: 6.02, 44.63; Q-p < 0.001) respectively. Gender-based PP were $30.61 \%$ (95\% CI: 22.95 , 39.51; Q-p < 0.001) and 31.85\% (95\% CI: 21.79, 43.94; Q$\mathrm{p}<0.001)$ for females and males respectively. Pooled prevalence reported in both HIV-patients 31.68\% (95\% CI: 20.53, 45.41; Q-p <0.001) and pregnant women
40.25\% (95\% CI: 33.19, 47.73; Q-p < 0.001) were significantly higher $(\mathrm{p}<0.001)$ than that among normal individuals $23.32 \%$ (95\% CI: 17.25 , 30.75; Q-p: 0.001). Overall heterogeneity was $97.64 \%$ with a range of 85.76 to $99.17 \%$ (Tables 2 and 3).

Publication bias, sensitivity and meta-regression analyses The funnel plots (Fig. 5) and their respective bias coefficients for studies published in Nigeria as a whole (b: -3.48; 95\% CI: - 7.53, 0.58; $p$ : 0.091), northern (b: -3.10; $95 \% \mathrm{CI}:-7.90,1.71 ; p: 0.194)$ and southern regions (b: -5.03; 95\% CI: - 11.05, 0.99; $p$ : 0.098) suggest insignificant publication bias. No outlying study capable of causing publication bias was identified and removed by the Duval and Tweedie's trim and fill method (Additional file 4). As in Additional file 5, the sensitivity tests showed that all single-study omission estimates were within the $95 \% \mathrm{CI}$ of the overall PP.

Meta-regression analysis (Tables 2 and 3) suggests that geographic regions $(\mathrm{Q}: 1.89 ; d f: 4 ; p$ : 0.756), sample size (Q: 0.53; $d f: 3 ; p: 0.913)$, age (Q: $0.57 ; d f: 1 ; p: 0.451)$ and gender of participants (Q: $0.04 ; d f: 1 ; p: 0.835)$ were unlikely to be the sources of heterogeneity in the present 
Table 2 Pooled prevalence of T. gondii infection in humans in Nigeria based of sub-groups

\begin{tabular}{|c|c|c|c|c|c|c|c|c|c|c|}
\hline \multirow[t]{2}{*}{ Variables } & \multirow{2}{*}{$\begin{array}{l}\text { No. of } \\
\text { Studies }\end{array}$} & \multicolumn{3}{|c|}{ Pooled Estimates } & \multirow[t]{2}{*}{$(95 \% \mathrm{Cl})$} & \multicolumn{3}{|c|}{ Heterogeneity } & \multicolumn{2}{|c|}{ Meta-regression } \\
\hline & & Sample size & Cases & Prev. (\%) & & Q-value & $I^{2}(\%)$ & Q-p & $\overline{\boldsymbol{P} \text {-value }}$ & OR $(95 \% \mathrm{Cl})$ \\
\hline \multicolumn{11}{|l|}{ Region } \\
\hline South-west & 19 & 5133 & 1880 & 31.70 & $23.86,40.74$ & 618.15 & 97.09 & $<0.001$ & \multirow[t]{5}{*}{0.756} & $-0.10(-0.80,0.61)$ \\
\hline South-south & 8 & 5412 & 2148 & 41.00 & $25.61,58.37$ & 825.41 & 99.15 & $<0.001$ & & $-0.15(-1.10,0.81)$ \\
\hline North-west & 10 & 2389 & 766 & 32.52 & $25.03,41.03$ & 116.68 & 92.29 & $<0.001$ & & $0.10(-0.59,0.80)$ \\
\hline North-east & 4 & 820 & 281 & 28.58 & $16.28,45.17$ & 58.84 & 94.90 & $<0.001$ & & $0.41(-0.32,1.14)$ \\
\hline North-central & 9 & 2476 & 759 & 29.58 & $18.54,43.66$ & 313.91 & 97.45 & $<0.001$ & & Reference \\
\hline \multicolumn{11}{|l|}{ MOD } \\
\hline RSAT & 3 & 407 & 73 & 14.41 & $5.32,33.54$ & 23.60 & 91.53 & $<0.001$ & \multirow[t]{5}{*}{$<0.001$} & $-2.87(-4.23,-1.51)$ \\
\hline Others & 11 & 4386 & 1169 & 34.79 & $21.32,51.24$ & 731.36 & 98.63 & $<0.001$ & & $-1.76(-2.81,-0.71)$ \\
\hline HAT & 4 & 1129 & 386 & 23.71 & $12.85,39.58$ & 35.54 & 91.56 & $<0.001$ & & $-2.34(-3.62,-1.07)$ \\
\hline ELISA & 28 & 8283 & 2941 & 31.62 & $26.39,37.37$ & 740.87 & 96.36 & $<0.001$ & & $-1.90(-2.88,-0.92)$ \\
\hline Dye Test & 4 & 2025 & 1265 & 74.29 & $57.49,86.06$ & 46.33 & 93.53 & $<0.001$ & & Reference \\
\hline \multicolumn{11}{|l|}{ Study period } \\
\hline 2006-2019 & 37 & 11,708 & 3586 & 28.75 & $23.44,34.71$ & 1420.79 & 97.47 & $<0.001$ & \multirow[t]{4}{*}{0.003} & $-2.76(-4.48,-1.05)$ \\
\hline 1991-2005 & 5 & 1543 & 722 & 44.60 & $27.46,63.13$ & 172.73 & 97.68 & $<0.001$ & & $-2.07(-3.92,-0.23)$ \\
\hline 1976-1990 & 6 & 2956 & 1506 & 41.93 & $27.81,57.51$ & 218.12 & 97.71 & $<0.001$ & & $-2.19(-4.01,-0.36)$ \\
\hline 1960-1975 & 2 & 23 & 20 & 86.82 & $66.13,95.69$ & 0.09 & 0.00 & 0.760 & & Reference \\
\hline \multicolumn{11}{|l|}{ Sample size } \\
\hline$>450$ & 7 & 6690 & 2524 & 36.64 & $24.15,51.23$ & 721.84 & 99.17 & $<0.001$ & \multirow[t]{4}{*}{0.913} & $0.19(-0.65,1.03)$ \\
\hline $301-450$ & 13 & 4704 & 1663 & 30.22 & $19.87,43.07$ & 790.96 & 98.48 & $<0.001$ & & $-0.09(-0.81,0.63)$ \\
\hline $151-300$ & 18 & 3976 & 1398 & 33.68 & $27.00,41.08$ & 354.78 & 95.21 & $<0.001$ & & $0.06(-0.62,0.73)$ \\
\hline$\leq 150$ & 12 & 860 & 249 & 32.59 & $18.93,50.04$ & 160.68 & 93.15 & $<0.001$ & & Reference \\
\hline Overall & 50 & 16,230 & 5834 & 32.92 & $27.89,38.37$ & 2071.70 & 97.64 & $<0.001$ & & \\
\hline
\end{tabular}

CI Confidence interval; ELISA Enzyme linked immunosorbent assay; HAT Haemagglutination test, LAT Latex agglutination test; PCR Polymerase chain reaction; RSAT Rapid slide agglutination test; $l^{2}$ Inverse variance index; MOD Method of diagnosis; OR Odds Ratio; Prev. Prevalence; $Q-p$ Cochran's $p$-value

Table 3 Pooled prevalence of Toxoplasma gondii infections in relation to age, gender and characteristics of study population

\begin{tabular}{|c|c|c|c|c|c|c|c|c|c|c|}
\hline \multirow[t]{2}{*}{ Variables } & \multirow{2}{*}{$\begin{array}{l}\text { No. of } \\
\text { Studies }\end{array}$} & \multicolumn{3}{|c|}{ Pooled Estimates } & \multirow[t]{2}{*}{$(95 \%$ Cl) } & \multicolumn{3}{|c|}{ Heterogeneity } & \multicolumn{2}{|c|}{ Meta-regression } \\
\hline & & Sample size & Cases & Prev. (\%) & & Q-value & $I^{2}(\%)$ & Q-p & $\overline{\boldsymbol{P} \text {-value }}$ & OR (95\% Cl) \\
\hline \multicolumn{11}{|l|}{ Age $^{*}$} \\
\hline Children & 7 & 1365 & 551 & 18.52 & $6.02,44.63$ & 342.16 & 98.25 & $<0.001$ & 0.451 & $0.37(-0.59,1.33)$ \\
\hline Adults & 7 & 2790 & 1224 & 36.93 & $29.04,45.59$ & 106.08 & 94.34 & $<0.001$ & & Reference \\
\hline Total & 14 & 4155 & 1775 & 29.55 & $21.19,39.55$ & 448.80 & 97.10 & $<0.001$ & & \\
\hline Gender & & & & & & & & $<0.001$ & & \\
\hline Male & 15 & 2391 & 1052 & 31.85 & $21.79,43.94$ & 353.07 & 96.04 & $<0.001$ & 0.835 & $-0.07(-0.70,0.57)$ \\
\hline Female & 22 & 4263 & 1667 & 30.61 & $22.95,39.51$ & 620.71 & 96.62 & $<0.001$ & & Reference \\
\hline Total & 37 & 6654 & 2719 & 31.23 & $25.15,38.02$ & 981.86 & 96.33 & $<0.001$ & & \\
\hline \multicolumn{11}{|l|}{ Target Population } \\
\hline Pregnant women & 20 & 6560 & 2990 & 40.25 & $33.19,47.73$ & 600.05 & 96.83 & $<0.001$ & 0.034 & $0.35(-0.21,0.91)$ \\
\hline Healthy individuals & 11 & 1372 & 313 & 23.32 & $17.25,30.75$ & 70.24 & 85.76 & $<0.001$ & & $-0.49(-1.16,0.18)$ \\
\hline HIV patients & 16 & 4061 & 1163 & 31.68 & $20.53,45.41$ & 767.23 & 98.05 & $<0.001$ & & Reference \\
\hline Total & 47 & 11,993 & 4466 & 32.94 & $27.61,38.74$ & 1614.29 & 97.15 & $<0.001$ & & \\
\hline
\end{tabular}




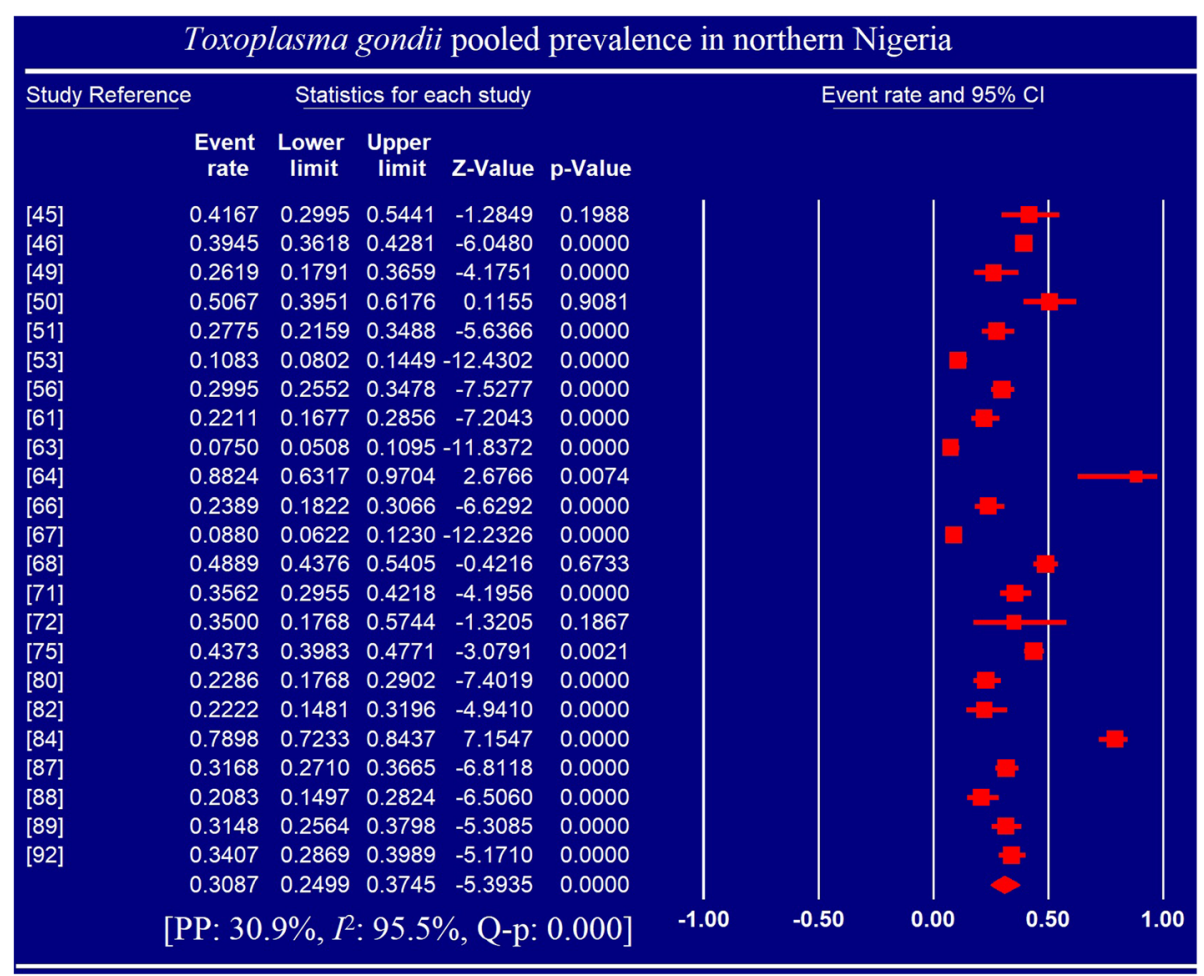

Fig. 3 Forest plot for the prevalence of Toxoplasma gondii infection in northern Nigeria

analysis. However, the year of conduct of the studies (Q: 13.72; $d f: 3 ; p: 0.003)$, methods of diagnosis employed by the studies (Q: $20.65 ; d f: 4 ; p<0.001)$ and characteristics of study population $(\mathrm{Q}: 6.00 ; d f: 2 ; p: 0.034)$ might be the possible causes of the heterogeneity in our analysis.

\section{Discussion}

Adequate understanding of the nationwide burden of toxoplasmosis is essential for effective prevention and control of the disease and its associated complications in immunocompromised individuals. Here, data from individual surveillance studies were harmonised across Nigeria with the sole aim of providing epidemiological information that may serve as a guide for disease monitoring and control in Nigeria.

We observed an overall PP of $32.92 \%$ which is consistent with a global report of $34.2 \%$ for middle income countries [94]. Our finding is however, higher than the 27.9\% reported from Mexico [95] but lower than the 74.7\% prevalence reported from Ethiopia [96]. T. gondii infection also showed geographical variations across Nigeria with the highest prevalence observed in the south-south region. Corroborating our finding, geographical variations within countries have been documented elsewhere. For instance, in sub-Saharan Africa, studies from Ethiopia reported prevalence of 68.4, 81.4 and $88.2 \%$ in the north-western, central and southern regions respectively $[19,22,97]$. More so, in Asia, studies from China documented prevalence of 8.4, 10.3, 12.3 and $21.6 \%$ in Anhui, Shanghai, Jilin and Yunnan provinces respectively [98-101]. Differences in weather conditions, eating habits, levels of environmental contamination with $T$. gondii oocysts, personal hygiene and human-cat contacts $[96,102]$ may be possible explanations for these variations across regions and countries.

The majority of the studies included in the analysis were diagnosed using ELISA. This may be due to the rapidity and accuracy of the method, convenience, ease of use, high sensitivity and specificity, cost effectiveness and the global acceptability of the test [103-105]. Studies diagnosed using the dye test recorded the highest disease prevalence probably due to its high specificity and sensitivity [106]. The serological tests conducted by the individual studies analysed targeted IgG (test for convalescent infection), IgM (test for recent or active infections) and their combination. Interestingly, $85 \%$ of the studies conducted on pregnant women detected IgM to identify activeness of infection which is a significant decision making stage to ameliorate or prevent congenital consequences based on stage of pregnancy.

The study showed over 58\% decline in the PP of $T$. gondii in Nigeria during the 59 years under review (1960-2019). The decline in recent years could have resulted from controlled movement of cats, improved 


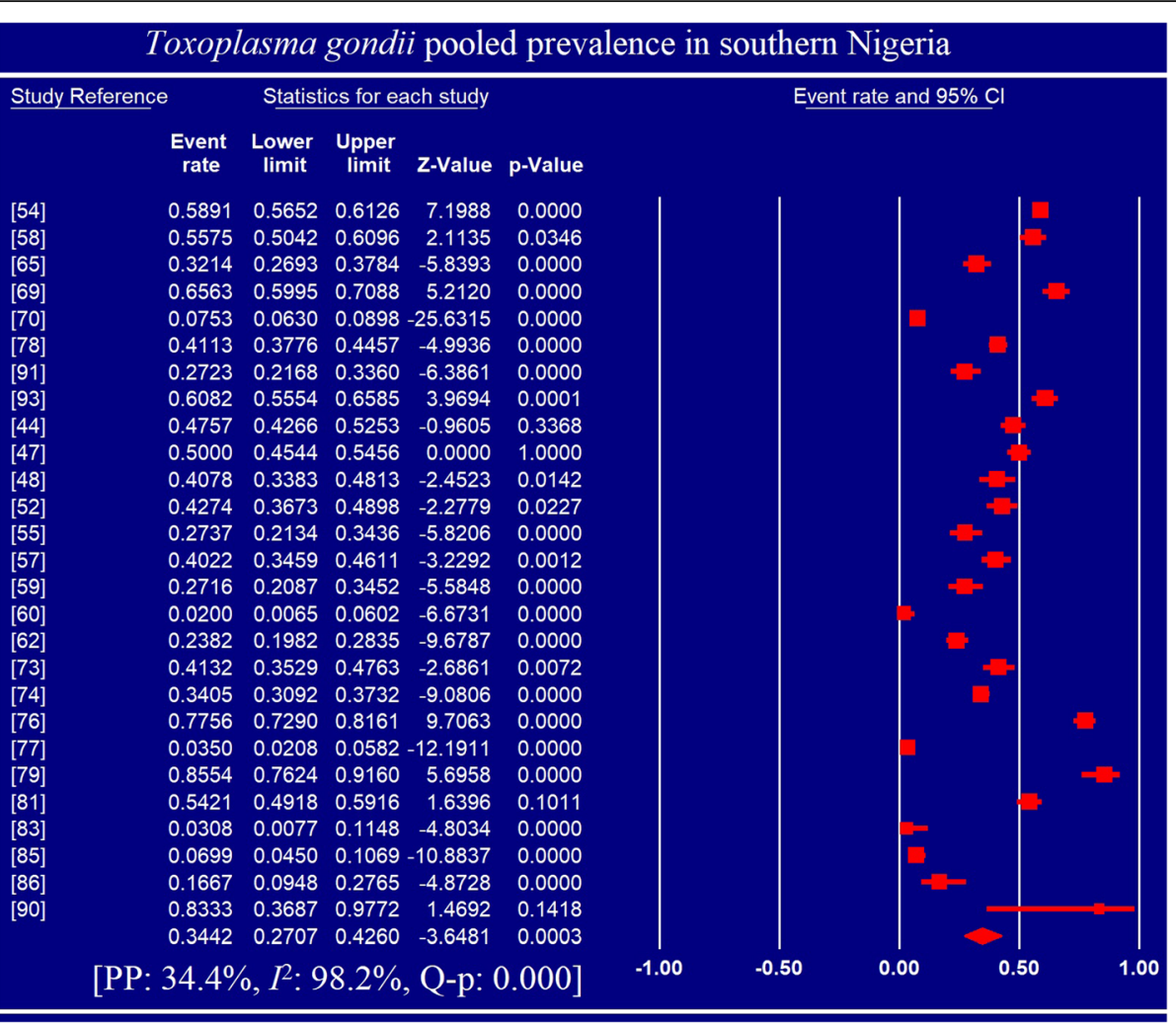

Fig. 4 Forest plot for the prevalence of Toxoplasma gondii infection in southern Nigeria

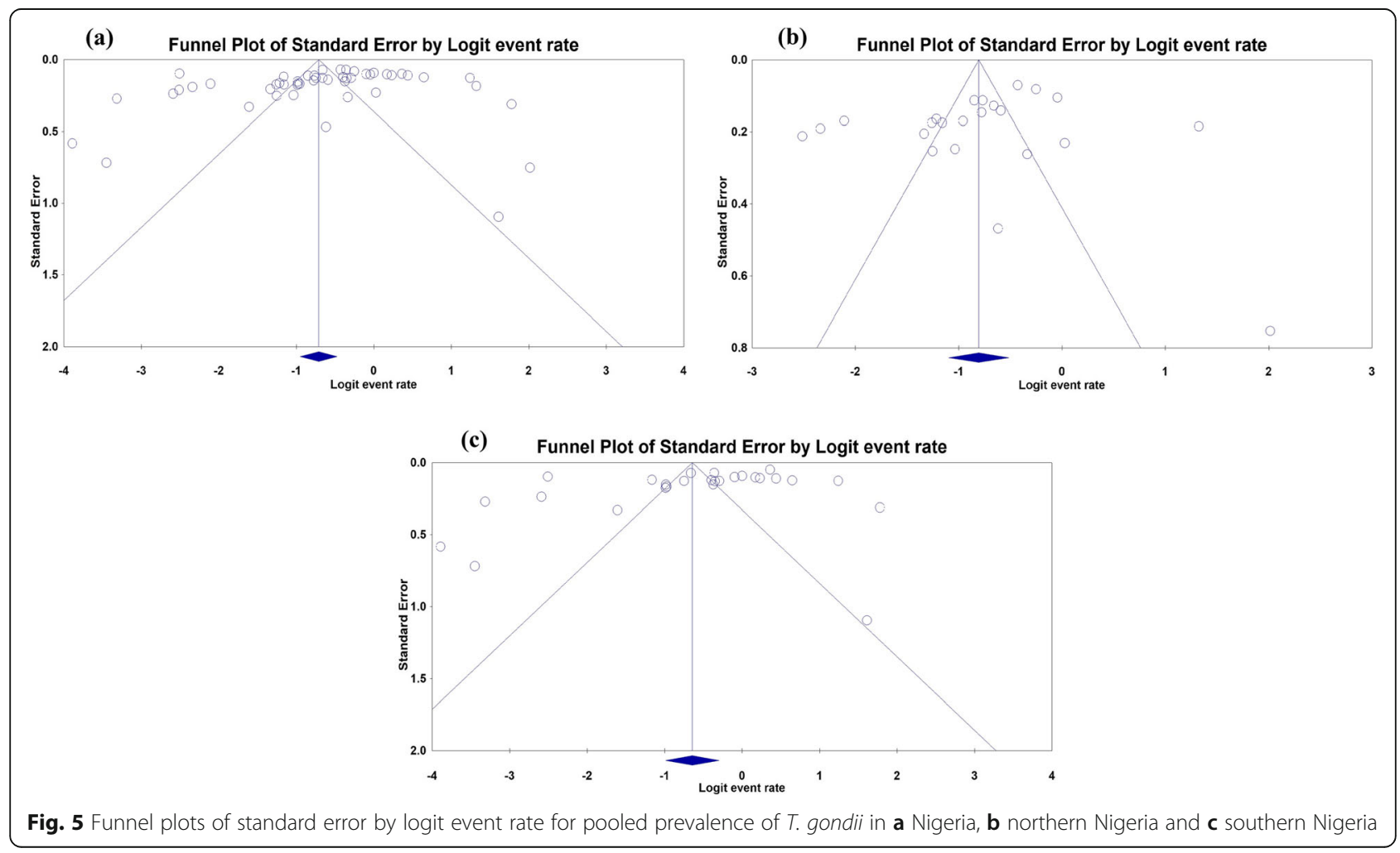


living standards, life styles and feeding habits that influence the transmission of this pathogen from cats and food animals to man. Other factors that may be responsible for the variations in $T$. gondii prevalence across study periods may include skills of the researchers involved as well as the sensitivity and specificity of the diagnostic methods employed by the individual studies. The majority of the studies were published within the twenty-first century in agreement with global report on $T$. gondii [94]. Increased interest on the pathogen arising from its association with severe complications in immunocompromised conditions like HIV infection, neoplasia and pregnancy may be a possible explanation.

The prevalence of $T$. gondii infection was higher in adults than children concurring reports from Mozambique [107] and Thailand [108]. This may be explained by the habits of eating undercooked roasted meat outside the home and possible intimacy of adults with pet cats. Corroborating a report from China [101], the present study observed a significantly higher prevalence in males than females. Contrary to our finding, AlQurashi et al. [7], Domingos et al. [107] and Tegegne et al. [109] reported higher prevalence in females in Saudi Arabia, Mozambique and Ethiopia, respectively.

Prevalence of $T$. gondii showed substantive heterogeneity among eligible studies reported across Nigeria. Metaregression analysis suggests that this high heterogeneity might be from sources including years in which the studies were conducted, methods of diagnosis employed by the individual studies, characteristics of the study population and not from study locations, sample sizes, as well as age and gender of participants. The sensitivity tests showed that all single-study omission estimates were within the $95 \% \mathrm{CI}$ of the overall prevalence, suggesting that the pooled prevalence of $T$. gondii was not substantially influenced by any single study. No significant publication bias was observed at alpha level of 0.05 with either Egger's test or Duval and Tweedie's method. The findings of the publication bias, sensitivity test and meta-regression substantiate the validity and reliability of the present analysis.

The PP of $40.25 \%$ observed among Nigerian pregnant women is higher than the range of $6.1-25.0 \%$ reported in countries like China [102, 110], Thailand [108] and Mexico [111]. The high prevalence among pregnant women is of major concern particularly in the ability of $T$. gondii to undergo intrauterine transmission and induce neonatal complications such as miscarriage, chorioretinitis, hydrocephalus, cerebral calcification and foetal death during pregnancy $[16,17]$. T. gondii PP in HIV-patients in Nigeria was $31.68 \%$ concurring with reports of 36.3 and $38.0 \%$ from Thailand [112] and South Africa [113] respectively. The present finding is however; grossly lower than reports of 87.45\% [17] and 90.0\% [114] from Ethiopia. Another major concern with this finding is the risk of HIV changing the asymptomatic course of $T$. gondii in these individuals to a severe cerebral toxoplasmosis which is manifested by headache, disorientation, drowsiness, hemiparesis, reflex changes and convulsion [12-14].

The public health implications of the present finding in a developing country like Nigeria with a collapse primary health care system which is supposed to take care of the health of the rural majority are increased morbidity and associated complications in pregnant women and PLWHA. Two approaches are pertinent to the control of T. gondii in Nigeria. First, reviewing disease control programmes in Nigeria to include staging of pregnancy and IgG avidity test particularly in Toxoplasma-seropositive pregnant women for possible treatment to prevent congenital consequences and the restriction of cat movement. Second, stakeholders in the area of veterinary public health can also ensure on-farm good agricultural practices as well as standardized veterinary meat inspection to curtail the zoonotic transmission of this pathogen from companion and food animals to man.

The present study has several limitations despite its contribution to knowledge. We could not include some potentially relevant studies which would have added to the understanding of $T$. gondii infection in Nigeria due to insufficiency of data. A whole region (south-east) was not represented in the analysis because no study was published from the region. Studies analysed were published from only 17 of the 36 States in Nigeria including the Federal Capital Territory and were concentrated in the south-west $(n=19)$. Over $95 \%$ of the studies included in the analysis relied on serological methods of diagnosis which are unreliable in immunocompromised people [42]. This suggests a possible underestimation of the PP reported by the present study in immunocompromised people in Nigeria. The substantive heterogeneity observed among studies indicates variations across studies which could be due to several factors including year of conduct of study, methods of diagnosis and characteristics of study population. This suggests that the present finding may not represent an absolute $T$. gondii situation in Nigeria, but may provide a guide for disease control policies and the direction for future studies.

\section{Conclusion}

$T$. gondii is moderately prevalent in Nigeria especially in the south-south region and among pregnant women and HIV-patients. The study showed over $58 \%$ decline in the PP of T. gondii during the 59 years reviewed (1960-2019). Age was a determining factor in the prevalence of $T$. gondii infection in Nigeria. To effectively control the disease, a holistic approach involving on-farm, environmental, public health and animal components are suggested. 


\section{Supplementary information}

Supplementary information accompanies this paper at https://doi.org/10. 1186/s12889-020-09015-7.

Additional file 1. Preferred Reporting Items for Systematic Reviews and Meta-Analyses (PRISMA) checklist.

Additional file 2. JBI critical appraisal instrument for studies reporting prevalence data.

Additional file 3. Quality assessment scores for eligible studies.

Additional file 4. Results for Egger regression analysis.

Additional file 5. Results for single study omission analysis.

\section{Abbreviations}

AIDS: Acquired immunodeficiency virus; AJOL: African Journals OnLine; $\mathrm{Cl}$ : Confidence interval; $d f$ : degree of freedom; ELISA: Enzyme linked immunosorbent assay; HAT: Haemagglutination test; HIV: Human immunodeficiency virus; ICT: Immunochromatographic test; I': Inverse variance index; LAT: Latex agglutination test; MOD: Method of diagnosis; PCR: Polymerase chain reaction; PLWHA: People living with HIV/AIDS; PP: Pooled prevalence; Prev: Prevalence; PRISMA: Preferred Reporting System for Systematic Reviews and Meta-Analyses; Q: Cochran's heterogeneity statistic; Q-p: Cochran's p-value; RSAT: Rapid slide agglutination test

\section{Acknowledgements}

We are grateful to the Editor-In-Chief of Nigerian Journal of Parasitology for providing some of the articles included in the analysis, and to all authors whose articles are included in this study. We also appreciate Mrs. Juliana Tije for assisting in literature search.

\section{Authors' contributions}

SNK: Conceived and designed the study, SNK and MNG: conducted literature search, identified articles, screened articles and extracted data. SNK:

Conducted statistical and meta-analyses and wrote the manuscript. Both authors read and approved the final manuscript.

\section{Funding}

Not applicable.

\section{Availability of data and materials}

The data supporting the conclusion of this article are all included in the article and Additional files 1-5.

\section{Ethics approval and consent to participate}

Not applicable.

\section{Consent for publication}

Not applicable.

\section{Competing interests}

The authors declare that they have no competing interests.

\section{Author details}

${ }^{1}$ Department of Veterinary Public Health and Preventive Medicine, University of Jos, PMB 2084, Jos, Nigeria. ²Department of Parasitology and Entomology, Modibbo Adama University of Technology, Yola, Adamawa State, Nigeria.

Received: 31 January 2020 Accepted: 29 May 2020

Published online: 06 June 2020

\section{References}

1. Dubey JP. Toxoplasmosis of animals and humans. 2nd ed. Boca Raton: CRC Press; 2010.

2. Paul RT, Pierpaolo M. The global burden of congenital toxoplasmosis: a systematic review. Bull Wld Hlth Organ. 2013;91:501-8.

3. Doudou Y, Renaud P, Coralie L, Jacqueline F, Hypolite S, Hypolite M, et al. Toxoplasmosis among pregnant women: high seroprevalence and risk factors in Kinshasa, Democratic Republic of Congo. Asian Pac J Trop Biomed. 2014;4:69-74. https://doi.org/10.1016/S2221-1691(14)60211-2.
4. Pappas G, Roussos N, Falagas ME. Toxoplasmosis snapshots: global status of Toxoplasma gondii seroprevalence and implications for pregnancy and congenital toxoplasmosis. Int J Parasitol. 2009;39:1385-94 https://doi.org/10. 1016/j.ijpara.2009.04.003.

5. Al-Karmi T, Behbehani K. Epidemiology of toxoplasmosis in Kuwait. II. Toxoplasma gondii in the desert rodent Meriones crassus. Tran R Soc Trop Med Hyg. 1980;74:745-6.

6. Abbas SA, Basalamah A, Serebour F, Alfonso M. The prevalence of Toxoplasma gondii antibodies in Saudi women and the outcome of congenital infection among new-borns in Saudi Arabia. Saudi Med J. 1986;7:346-54.

7. Al-Qurashi AR, Ghandour AM, Obied OE, Al-Mulhim A, Makki SM. Seroepidemiological study of Toxoplasma gondii infection in the human population in the eastern region. Saudi Med J. 2001;22(1):13-8.

8. Dabritz HA, Conrad PA. Cats and Toxoplasma: implications for public health. Zoon Pub HIth. 2010:57:34-52

9. Caballero-Ortega H, Uribe-Salas FJ, Conde-Glez CJ, Cedillo-Pelaez C, VargasVillavicencio JA, Luna-Pastén $\mathrm{H}$, et al. Sero-prevalence and national distribution of human toxoplasmosis in Mexico: analysis of the 2000 and 2006 national health surveys. Tran R Soc Trop Med Hyg. 2012;106(11):653-9. https://doi.org/10.1016/j.trstmh.2012.08.004.

10. Welker $Y$, Molina JM, Poirot C, Ferchal F, Decazes JM, Lagrange $P$, et al. Interaction between human immunodeficiency virus and Toxoplasma gondi replication in dually infected monocytoid cells. Infect Immun. 1993;61(4): $1596-8$

11. Bala S, Englund G, Kovacs J, Wahl L, Martin M, Sher A, et al. Toxoplasma gondii soluble products induce cytokine secretion by macrophages and potentiate in vitro replication of a monotropic strain of HIV. J Eukaryot Microbiol. 1994:41:75.

12. Barratt JL, Harkness J, Marriott D, Ellis JT, Stark D. Importance of non-enteric protozoan infections in immunocompromised people. Clin Microbiol Rev. 2010;23:795-836.

13. Robert-Gangneux F, Darde ML. Epidemiology of and diagnostic strategies for toxoplasmosis. Clin Microbiol Rev. 2012;25(2):264-96. https://doi.org/10. 1128/CMR.05013-11.

14. Machala L, Kodym P, Maly M, Geleneky M, Beran O, Jilich D. Toxoplasmosis in immunocompromised patients. Epidemiol Mikrobiol Imunol. 2015;64:59-65.

15. Alonso R, Heiman-Patterson T, Mancall EL. Cerebral toxoplasmosis in acquired immune deficiency syndrome. Arch Neurol. 1984:41:321-3.

16. Torgerson PR, Macpherson CN. The socioeconomic burden of parasitic zoonoses: global trends. Vet Parasitol. 2011;182(1):79-95. https://doi.org/10. 1016/j.vetpar.2011.07.017

17. Walle F, Kebede N, Tsegaye A, Kassa T. Sero-prevalence and risk factors for Toxoplasmosis in HIV infected and non-infected individuals in Bahir Dar Northwest Ethiopia. Parasit Vectors. 2013;6(15):8 http://www. parasitesandvectors.com/content/6/1/15.

18. Bessieres $\mathrm{MH}$, Berrebi A, Cassaing S, Fillaux J, Cambus JP, Berry A, et al. Diagnosis of congenital toxoplasmosis: prenatal and neonatal evaluation of methods used in Toulouse University Hospital and incidence of congenital toxoplasmosis. Mem Inst Oswaldo Cruz. 2009:104(2):389-92.

19. Gebremedhin EZ, Abebe AH, Tessema TS, Tullu KD, Medhin G, Vitale M, et al. Sero-epidemiology of Toxoplasma gondii infection in women of childbearing age in central Ethiopia. BMC Infect Dis. 2013;13(101):6. https://doi. org/10.1155/2015/170278.

20. Zumla A, Savva B, Wheeler RB, Hira SK, Luo NP, Kaleebu P, et al. Toxoplasma serology in Zambian and Ugandan patients infected with the human immunodeficiency virus. Tran R Soc Trop Med Hyg. 1991;85(2):227-9. https://doi.org/10.1016/0035-9203(91)90034-V.

21. Khalil KM, Ahmed AA, Elrayah LE. Sero-prevalence of Toxoplasma gondii infection in humans in Khartoum state, Sudan. Intern J Trop Med. 2012;7: $143-50$

22. Yohanes T, Debalke S, Zemene E. Latent Toxoplasma gondii infection and associated risk factors among HIV-infected individuals at Arba Minch hospital. South Ethiopia AIDS Res Treat. 2014;2014:6. https://doi.org/10.1155/ 2014/652941.

23. Mirambo MM, Mushi MF, Kivambe C. High sero-prevalence of specific Toxoplasma gondii lgG antibodies among HIV/AIDS patients with immunological failure attending a tertiary hospital in North-Western Tanzania. Tanz J Hlth Res. 2016:18:1-4.

24. Hagiwara E, Ito A, Shirai A, Kawada K, Okubo T, Amano T, et al. Seroprevalence of anti-Toxoplasma lgG antibody in Japanese patients with HIV infection. Kansenshogaku Zasshi. 2001;75:703-4. 
25. Rostami A, Keshavarz H, Shojaee S, Mohebali M, Meamar AR. Frequency of Toxoplasma gondii in HIV positive patients from west of Iran by ELISA and PCR. Iran J Parasitol. 2014;9:474-81.

26. Rahimi MT, Mahdavi SA, Javadian B, Javadian B, Rezaei R, Moosazadeh M, et al. High sero-prevalence of Toxoplasma gondii antibody in HIV/AIDS individuals from north of Iran. Iran J Parasitol. 2015;10:584-9.

27. Belanger F, Derouin F, Grangeot-Keros L, Meyer L. Incidence and risk factors of toxoplasmosis in a cohort of human immunodeficiency virus-infected patients: 1988-1995. Clin Infect Dis. 1999;28:575-81.

28. Đaković-Rode O, Židovec-Lepej S, Vodnica-Martucci M, Lasica PV, Begovac J. Prevalence of antibodies against Toxoplasma gondii in patients infected with human immunodeficiency virus in Croatia. Infektol Glas. 2010;30:5-10

29. Llenas-García J, Rubio R, Hernando A, Fiorante S, Maseda D, Matarranz M, et al. Clinico-epidemiological characteristics of HIV positive immigrants: study of 371 cases. Enferm Infecc Microbiol Clin. 2012;30(8):441-51. https:// doi.org/10.1016/j.eimc.2012.01.009.

30. Johns DG, Gill MJ. Sero-prevalence of cytomegalovirus, Toxoplasma gondii, syphilis, and hepatitis $B$ and $C$ virus infections in a regional population seropositive for HIV infection. Can J Infect Dis. 1998;9:209-14.

31. Falusi O, French AL, Seaberg EC, Tien PC, Watts DH, Minkoff H, et al. Prevalence and predictors of Toxoplasma seropositivity in women with and at risk for human immunodeficiency virus infection. Clin Infect Dis. 2002; 35(11):1414-7. https://doi.org/10.1086/344462.

32. O'Bryan TA, Okulicz JF, Bradley WP, Ganesan A, Merritt SE, Agan BK. Toxoplasma gondii sero-prevalence: 30-year trend in an HIV-infected US military cohort. Diagn Microbiol Infect Dis. 2016;84:34-5.

33. Pérez CC, Cerón Al, Fuentes LG, Zañartu SC, Balcells MME, Ajenjo HC, et al. Hepatitis B, C, Treponema pallidum and Toxoplasma gondii co-infections in HIV infected patients. Rev Med Chil. 2009;137:641-8.

34. Vidal JE, Diaz AV, de Oliveira AC, Dauar RF, Colombo FA. Pereira-Chioccola VL Importance of high lgG anti-Toxoplasma gondii titers and PCR detection of $T$ gondii DNA in peripheral blood samples for the diagnosis of AIDS-related cerebral toxoplasmosis: a case-control study. Braz J Infect Dis. 2011;15:356-9.

35. Xavier GA, Cademartori BG, Cunha FNA, Farias NA. Evaluation of seroepidemiological toxoplasmosis in HIV/AIDS patients in the south of Brazil. Rev Inst Med Trop Sao Paulo. 2013;55:25-30.

36. Moher D, Liberati A, Tetzlaff J, Altman DG. The PRISMA Group. Preferred reporting items for systematic reviews and meta-analyses: The PRISMA Statement. PLoS Med. 2009;6(7):e1000097. https://doi.org/10.1371/journal. pmed. 1000097.

37. Munn Z, Moola S, Lisy K, Riitano D, Tufanaru C. Methodological guidance for systematic reviews of observational epidemiological studies reporting prevalence and incidence data. Int J Evid Based Healthc. 2015;13:147-53.

38. Hedges LV, Vevea JL. Fixed- and random-effects models in meta-analysis. Psychol Meth. 1998;3:486-504.

39. Higgins JP, Thompson SG. Quantifying heterogeneity in a meta-analysis. Stat Meth. 2002;21:1539-58.

40. Higgins JPT, Thompson SG, Deeks JJ, Altman DG. Measuring inconsistency in meta-analyses. BMJ. 2003;327:557-60.

41. Egger M, Smith GD, Schneider M, Minder C. Bias in meta-analysis detected by a simple graphical test. BMJ. 1997;315:629-34.

42. Duval S, Tweedie R. Trim and fill: a simple funnel-plot-based method of testing and adjusting for publication bias in meta-analysis. Biometrics. 2000; 56:455-63.

43. Gao L, Zhang L, Jin Q. Meta-analysis: prevalence of HIV infection and syphilis among MSM in China. Sex Transm Infect. 2009;85:354-8.

44. Adeniyi OT, Adekola SS, Oladipo OM. Sero-epidemiology of toxoplasmosis among pregnant women in Osogbo, southwestern, Nigeria. J Infect Dis Immun. 2018;10(2):8-16.

45. Adepoju FG, Olawumi HO, Adekoya BJ. HIV sero-positivity and related eye diseases in UITH, Ilorin. Niger Postgrad Med J. 2007;14(2):163-5.

46. Aganga $\mathrm{AO}, \mathrm{Umoh} J U$, Ekwempu CC. Seroprevalence studies of human Toxoplasma infection in Zaria, Nigeria. Nig J Parasitol. 1990;11:159-64.

47. Akanmu AS, Osunkalu VO, Ofomah JN, Olowoselu FO. Pattern of demographic risk factors in the seroprevalence of anti-Toxoplasma gondii antibodies in HIV infected patients at the Lagos University teaching hospital. Nig Quart J Hosp Med. 2010;20(1):1-4.

48. Akinbami AA, Adewunmi AA, Rabiu KA, Wright KO, Dosunmu AO, Dada MO, et al. Seroprevalence of Toxoplasma gondii antibodies amongst pregnant women at the Lagos State University teaching hospital, Nigeria. Niger Postgrad Med J. 2010;17(2):164-7.
49. Alayande MO, Edungbola LD, Fabiyi JP, Awosan Kl, Babatunde SK, Suleiman $\mathrm{Al}$, et al. Seroprevalence of Toxoplasma infection in stored sera of HIV individual in Sokoto, Nigeria. Afr J Microbiol Res. 2012a;6(5):972-5. https:// doi.org/10.5897/AJMR11.1014.

50. Alayande MO, Edungbola LD, Fabiyi JP, Faleke OO, Awosan KJ, Fadeyi A, et al. Sero-prevalence of Toxoplasma gondii infection among abattoir workers in Sokoto, Nigeria. Sahel Med J. 2012b;15:80-4.

51. Alayande MO, Edungbola LD, Fabiyi JP, Awosan KJ. Occurrence of antibody to Toxoplasma infection among pregnant women with obstetric histories and at different trimesters in Sokoto, Northwest Nigeria. Am J Res Comm. 2013;1(9):240-7.

52. Amoo A, Njaanake K, Dada-Adegbola HO, Omosa-Manyonyi G. Toxoplasmosis among blood donors: unsafe blood transfusion in Ibadan, Southwest Nigeria. J Appl Hematol. 2019;10:120-5.

53. Amuta EU, Amali O, Jacob SE, Houmsou RS. Toxoplasma gondii IgG antibodies in HIV/AIDS patients attending hospitals in Makurdi metropolis, Benue state, Nigeria. Intern J Med Biomed Res. 2012;1(3):186-92.

54. Arene FOI. The prevalence of toxoplasmosis among inhabitants of the Niger Delta. Folia Parasitol. 1986;33:311-4.

55. Awobode HO, Olubi IC. Prevalence of Toxoplasma gondii and HIV infection among pregnant women in Ibadan north local government, Oyo state. Afr J Med Medical Sci. 2014;43:39-45.

56. Bata SI, Ajogi I, Umoh JU, Lawal I, Randawa AJ. Sero-prevalence and risk factors for Toxoplasma gondii infection among antenatal women in Zaria, Nigeria. Res J Med Medical Sci. 2009;4(2):483-8.

57. Deji-Agboola AM, Busari OS, Osinupebi OA, Amoo AOJ. Sero-prevalence of Toxoplasma gondii antibodies among pregnant women attending antenatal clinic of the Federal Medical Centre, Lagos, Nigeria. Intern J Biol Med Res. 2011;2(4):1135-9.

58. Ekanem US, Moses AE, Abraham EG, Motilewa OO, Umo AN, Uwah Al, Itina El. Seroprevalence of anti-Toxoplasma gondii lgG antibody and risk factors among abattoir workers in Uyo, southern Nigeria. Niger J Clin Pract. 2018;21:1662-9.

59. Ekweozor CC, Okpala LE, Bamgboye AE, Jegede O. Toxoplasmosis: antiToxoplasma lgG antibody levels in patients with lymphoid neoplasia in Ibadan, Nigeria. Afr J Med Medical Sci. 1994;23(4):347-53.

60. Enitan SS, Adejumo AO, Oluremi AS, lleoma E, Adejumo EN, Oyedele TF, Enitan CB. Sero-prevalence of anti-toxoplasma Gondii lgM and IgG antibodies among young adults with history of ocular infection in SouthWestern Nigeria. EAS J Parasitol Infect Dis. 2019;1(6):133-43.

61. Goni BW, Bakki B, Kida IM, Yusuph H, Zailani SB, Mustapha SK, et al. Seroprevalence of IgG anti-T. gondii antibody among HIV infected patients in Maiduguri, north eastern Nigeria. J Med Sci. 2012;6:7-14.

62. Gyang VP, Akinwale OP, Lee Y, Chuang T, Orok A, Ajibaye O, et al. Toxoplasma gondii infection: sero-prevalence and associated risk factors among primary schoolchildren in Lagos City, southern Nigeria. Rev da Soc Bras de Med Trop. 2015;48(1):56-63. https://doi.org/10.1590/0037-8682-0310-2014.

63. Ibrahim A, Kumurya AS, Yahaya H, Abdu A, Ado BK, Ella EE, et al. T-cell mediated immune responses in obstetric population acutely infected with toxoplasmosis in Kano, Nigeria. UMYU J Microbiol Res. 2017;2(1):217-27.

64. Iverson HA, Hursh MD, Lewis A. Toxoplasmosis serological studies on patients with chorio-retinitis in Nigeria. Brit J Ophthal. 1960;44:537-40.

65. James BO, Agbonile IO, Okolo M, Lawani AO, Omoaregba JO. Prevalence of Toxoplasma gondii infection among individuals with severe mental illness in Nigeria: a case control study. Path Glob Hlth. 2013;107(4):189-93. https://doi. org/10.1179/2047773213Y.0000000093.

66. Kamani J, Mani AU, Egwu GO, Kumshe HA. Sero-prevalence of human infection with Toxoplasma gondii and the associated risk factors, in Maiduguri, Borno state, Nigeria. Ann Trop Med Parasitol. 2009;103(4):317-21.

67. Mirabeau TY, Ebikade AO. Low sero-prevalence of Toxoplasma gondii lgG and IgM antibodies in HIV sero-positive patients attending National Hospital, Abuja, Nigeria. J Life Sci. 2012;6:481-4.

68. Nasir IA, Aderinsayo AH, Mele HU, Aliyu MM. Prevalence and associated risk factors of Toxoplasma gondii antibodies among pregnant women attending Maiduguri teaching hospital, Nigeria. J Med Sci. 2015;15(3):147-54. https:// doi.org/10.3923/jms.2015.147.154.

69. Oboro IL, Obunge OK, Wariso KT. Sero-epidemiology of toxoplasmosis among pregnant women in the University of Port Harcourt Teaching Hospital, Nigeria. Nig Hlth J. 2016;16(1):12.

70. Ogefere HO, Ali AS, Omoregie R. Effect of CD4 count on the prevalence of IgG and lgM anti-toxoplasma antibodies among HIV positive patients in Benin City, Edo state, Nigeria. J Med Lab Sci. 2019;29(3):54-60. 
71. Ogoina D, Onyemelukwe GC, Musa BO, Obiako R. Sero-prevalence of IgM and IgG antibodies to Toxoplasma infection in healthy and HIV-positive adults from northern Nigeria. J Infect Dev Ctries. 2013;7(5):398-403. https:// doi.org/10.3855/jidc.0000.

72. Okoh AEJ, Agbonlahor DE, Momoh M. Toxoplasmosis in Nigeria- a serological survey. Trop Anim Hlth Prod. 1981:13:137-43.

73. Okwuzu JO, Odunukwe NN, Ezechi OC, Gbajabiamila TA, Musa AZ, Ezeobi PM, et al. Toxoplasma gondii infection in HIV/AIDS: prevalence and risk factors. Afr J Clin Exp Microbiol. 2014;15(2):97-102 https://doi.org/10.4314/ ajcem.v15i2.7

74. Okwuzu JO, Otubanjo AO, Ezechi OC, Idowu ET, Odunukwe NN, Okoye RN, et al. Toxoplasma gondii infection among HAART-naive HIV-positive patients and HIV-negatives in Lagos state, Nigeria. Intern J Microbiol Immunol Res. 2015:3:1-8.

75. Olusi T, Gross U, Ajayi J. High incidence of toxoplasmosis during pregnancy in Nigeria. Scand J Infect Dis. 1996;28(6):645-6.

76. Onadeko MO, Joynson DH, Payne RA. The prevalence of Toxoplasma infection among pregnant women in Ibadan, Nigeria. J Trop Med Hyg. 1992;95(2):143-5.

77. Onakoya AO, Odeyemi MG, Aribaba OT, Akinsola FB. Ocular findings in acquired immunodeficiency syndrome patients in Lagos, Nigeria. Nig Quart J Hosp Med. 2012;22(1):52-7.

78. Onosakponome EO, Wokem GN, Abah AE. Comparison of ELISA and Rapid Immunochromatographic tests in diagnosis of toxoplasmosis in Port Harcourt, Nigeria. Intern J Trop Dis. 2020;41(1):54-9.

79. Oshinaike OO, Okubadejo NU, Ojini Fl, Danesi MA. A preliminary study of the frequency of focal neurological deficits in HIV/AIDS patients seropositive for Toxoplasma gondii lgG in Lagos, Nigeria. Nig Quart J Hosp Med. 2010;20(3):104-7.

80. Osiyemi TIO, Synge EMM, Agbonlaho DE, Agbavwe R. The prevalence of Toxoplasma gondii antibodies in man in plateau state and meat animals in Nigeria. Trans R Soc Trop Med Hyg. 1985;79:21-3.

81. Osunkalu VO, Akanmu SA, Ofomah NJ, Onyiaorah IV, Adediran AA, Akinde $\mathrm{RO}$, et al. Sero-prevalence of Toxoplasma gondii lgG antibody in HIV-infected patients at the Lagos University teaching hospital. HIV/AIDS Res Palliative Care. 2011;3:101-5. https://doi.org/10.2147/HIV. S15532.

82. Oyinloye SO, Igila-Atsibee M, Ajayi B, Lawan MA. Serological screening for ante-natal toxoplasmosis in Maiduguri municipal council, Borno state, Nigeria. Afr J Clin Exp Microbiol. 2014;15(2):91-6. https://doi.org/10.4314/ ajcem.v15i2.6

83. Sanyaolu AO, Oyibo WA, Iriemenam NC, Badaru OS. Sero-prevalence study of parasitic infections among HIV positive and negative patients in Lagos, Nigeria. Afr J Clin Exp Microbiol. 2016;17(2):88-96. https://doi.org/10.4314/ ajcem.v17i2.3

84. Sixl W, Rosegger H, Schneeweiss H, Withalm H, Schuhmann G. Serological investigations in Nigeria for anthropozoonoses in human sera: brucellosis, echinococcosis, toxoplasmosis, chlamydial diseases, listeriosis, rickettsiosis (Coxiella burneti and Rickettsia conori). J Hyg Epidemiol Microbiol Immunol. 1987;31(4):493-5.

85. Sowemimo OA, Wuc T, Leed $Y$, Asaolua SO, Chuange T, Akinwalef OP, et al. Toxoplasma gondii: sero-prevalence and associated risk factors among preschool-aged children in Osun state, Nigeria. Tran R Soc Trop Med Hyg. 2018;00:1-6. https://doi.org/10.1093/trstmh/try083.

86. Thomas $V$, Fabiyi A, Adeniyi A. Prevalence of antibodies to parasitic infections in Nigerian children. J Trop Med Hyg. 1981;84(3):113-6.

87. Uneke CJ, Duhlinska DD, Njoku MO, Ngwu BAF. Sero-prevalence of acquired toxoplasmosis in HIV-infected and apparently healthy individuals in Jos, Nigeria. Parasitol. 2005;47:233-6.

88. Uneke CJ, Duhlinska DD, Ngwu BA, Njoku MO. Sero-prevalence of Toxoplasma gondii infection in Kwal, a rural district of plateau-Nigeria. Afr Med Medical Sci. 2007;36(2):109-13.

89. Uttah EC, Ajang R, Ogbeche J, Etta H, Etim L. Comparative sero-prevalence and risk factors of toxoplasmosis among three subgroups in Nigeria. J Natural Sci Res. 2013;3(8):23-8.

90. Wiseman RA, Woodruff AW. Toxoplasmal and toxocaral infections: a clinical investigation into their relationship. Brit Med J. 1970;4:152-3.

91. Wokem GN, Onosakponome E, Arene FOI. Sero-prevalence of toxoplasmosis and associated risk factors among pregnant women attending antenatal clinic in the University of Port Harcourt Teaching Hospital, Rivers state, Nigeria Nig J Parasitol 2018;39(1): 98-102.
92. Yusuf AM, Yahaya S, Azeez-Akande O. Sero-prevalence and risk factors of Toxoplasma gondii infection (toxoplasmosis) among HIV seropositive pregnant women in a tertiary healthcare centre, Kano, Northern Nigeria. J Med Medical Sci. 2016;7(1):001-5. https://doi.org/10.14303/jmms.2016.017.

93. Yusuf E, Airauhi LU. Sero-prevalence of Toxoplasma gondii among HIV patients in University of Benin Teaching Hospital (UBTH), Benin City, Edo state. Nigeria Borno Med J. 2017;14(1):78-84.

94. Wang Z, Wang S, Liu H, Ma H, Li Z, Wei F, et al. Prevalence and burden of Toxoplasma gondii infection in HIV-infected people: a systematic review and meta-analysis. Lancet HIV. 2017;4:e177-88. https://doi.org/10.1016/S23523018(17)30005-X

95. Galvan-Ramirez ML, Troyo R, Roman S, Calvillo-Sanchez C, Bernal-Redondo R. A systematic review and meta-analysis of Toxoplasma gondii infection among the Mexican population. Parasit Vectors. 2012;5(271):12. https://doi. org/10.1186/1756-3305-5-271.

96. Gebremedhin EZ, Tadesse G. A meta-analysis of the prevalence of Toxoplasma gondii in animals and humans in Ethiopia. Parasit Vectors. 2015; 8(291):9. https://doi.org/10.1186/s13071-015-0901-7.

97. Agmas B, Tesfaye R, Koye DN. Seroprevalence of Toxoplasma gondii infection and associated risk factors among pregnant women in Debre Tabor, Northwest Ethiopia. BMC Res Notes. 2015;8(107):7. https://doi.org/10. 1186/s13104-015-1083-2.

98. Xiao Y, Yin J, Jiang N, Xiang M, Hao L, Lu H, et al. Sero-epidemiology of human Toxoplasma gondii infection in China. BMC Infect Dis. 2010;10(4):5 http://www.biomedcentral.com/1471-2334/10/4.

99. Tao YL, Zhao XT, Fu YF, Tang YF, Li SS, Cheng XJ. Serological survey of Toxoplasma gondii infection among public health practitioners in Xuhui District of Shanghai. Chin J Parasitol Parasit Dis. 2012;30:495-7.

100. Li HL, Dong L, Li Q, Zhang L. Sero-epidemiology of Toxoplasma gondii infection in Bai and Han ethnic groups in South-Western China. Epidemiol Infect. 2015;143(4):881-6. https://doi.org/10.1017/S0950268814001551.

101. Wang L, He L, Meng D, Chen Z, Wen H, Fang G, et al. Sero-prevalence and genetic characterization of Toxoplasma gondii in cancer patients in Anhui Province, Eastern China. Parasit Vectors. 2015;8(162):7. https://doi.org/10. 1186/s13071-015-0778-5

102. Liu Q, Wei F, Gao S, Jiang L, Lian H, Yuan B, et al. Toxoplasma gondii infection in pregnant women in China. Tran R Soc Trop Med Hyg. 2009; 103(2):162-6. https://doi.org/10.1016/j.trstmh.2008.07.008.

103. Chen R, Lu S, Lou D, Zeng X, Ding Z, Wen L, et al. Evaluation of a rapid ELISA technique for detection of circulating antigens of Toxoplasma gondii. Microbiol Immun. 2008;52(3):180-7. https://doi.org/10.1111/j.1348-0421.2008. 00020.x.

104. Nagaty IM, Ibrahim KM, Abdel-Tawab AH, Hassan AE. Diagnosis of Toxoplasma gondii by ELISA and PCR in mothers and their infants. J Egypt Soc Parasitol. 2009:39(2):625-32.

105. Turunen $H$, Vuorio KA, Leinikki PO. Determination of $\lg G, \lg M$ and $\lg A$ antibody responses in human toxoplasmosis by enzyme-linked immunosorbent assay (ELISA). Scand J Infect Dis. 1983;15:307-11.

106. Reiter-Owona I, Petersen E, Joynson D, Aspöck H, Dardé ML, Disko R, et al. The past and present role of the Sabin-Feldman dye test in the serodiagnosis of toxoplasmosis. Bull Wld HIth Organ. 1999;77(11):929-35.

107. Domingos A, Ito LS, Coelho E, Lucio JM, Matida LH, Ramos AN Jr. Seroprevalence of Toxoplasma gondii lgG antibody in HIV/AIDS-infected individuals in Maputo, Mozambique. Rev Saude Publica. 2013;47:890-6.

108. Andiappan H, Nissapatorn V, Sawangjaroen N, Chemoh W, Lau YL, Kumar T, et al. Toxoplasma infection in pregnant women: a current status in Songklanagarind hospital, southern Thailand. Parasit Vectors. 2014;7(239). https://doi.org/10.1186/1756-3305-7-239.

109. Tegegne D, Abdurahaman M, Mosissa T, Yohannes M. Anti-Toxoplasma antibodies prevalence and associated risk factors among HIV patients. Asian Pac J Trop Med. 2016;9(5):460-4 https://doi.org/10.1016/j.apjtm.2016.03.034.

110. Jenum PA, Stray-Pedersen B, Melby KK, Kapperud G, Whitelaw A, Eskild A, et al. Incidence of Toxoplasma gondii infection in 35,940 pregnant women in Norway and pregnancy outcome for infected women. J Clin Microbiol. 1998;36(10):2900-6.

111. Alvarado-Esquivel C, Sifuentes-Álvarez A, Narro-Duarte SG, Estrada-Martínez S, Díaz-García JH, Liesenfeld O, et al. Sero-epidemiology of Toxoplasma gondii infection in pregnant women in a public hospital in northern Mexico. BMC Infect Dis. 2006:6(113), 7. https://doi.org/10.1186/1471-2334-6-113.

112. Cong W, Dong XY, Meng QF, Zhou N, Wang XY, Huang SY, et al. Toxoplasma gondii infection in pregnant women: a sero-prevalence and 
case-control study in eastern China. Biomed Res Int. 2015;2015:6. https://doi. org/10.1155/2015/170278.

113. Shimelis T, Tebeje M, Tadesse E, Tegbaru B, Terefe A. Sero-prevalence of latent Toxoplasma gondii infection among HIV-infected and HIV-uninfected people in Addis Ababa, Ethiopia: A comparative cross-sectional study. BMC Res Notes. 2009;2(213):5. https://doi.org/10.1186/1756-0500-2-213.

114. Chemoh W, Sawangjaroen N, Siripaitoon P, Andiappan H, Hortiwakul T, Sermwittayawong $\mathrm{N}$, et al. Toxoplasma gondii - prevalence and risk factors in HIV-infected patients from Songklanagarind hospital, Southern Thailand. Fron Microbiol. 2015;6(1304). https://doi.org/10.3389/fmicb.2015.01304.

\section{Publisher's Note}

Springer Nature remains neutral with regard to jurisdictional claims in published maps and institutional affiliations.

Ready to submit your research? Choose BMC and benefit from:

- fast, convenient online submission

- thorough peer review by experienced researchers in your field

- rapid publication on acceptance

- support for research data, including large and complex data types

- gold Open Access which fosters wider collaboration and increased citations

- maximum visibility for your research: over $100 \mathrm{M}$ website views per year

At $\mathrm{BMC}$, research is always in progress.

Learn more biomedcentral.com/submissions 